Katarina Bogunović Hočevar

Filozofska fakulteta Univerze v Ljubljani

Philosophical Faculty, University of Ljubljana

\title{
Romantika kot glasbenozgodovinsko obdobje - med zakoreninjenostjo in negotovostjo
}

\section{Romanticism as a Period of Musical History - between Rootedness and Uncertainty}

Prejeto: 15 . april 2009

Sprejeto: 1. maj 2009

Ključne besede: romantika, zgodovina glasbe, obdobje, recepcija glasbe

IZVLEČEK

Razprava skuša pokazati, kako novejši muzikološki diskurz opredeljuje in definira pojem romantika kot oznako za glasbenozgodovinsko obdobje.
Received: 15th April 2009

Accepted: 1st May 2009

Keywords: romanticism, history of music, period, reception of music

ABSTRACT

The article tries to detect the ways of new musicological discourses defining Romanticism as a designation of a period in music history.

Časovno zamejevanje romantike kot pojma za glasbenozgodovinsko obdobje je po Eggebrecthovem mnenju tako raznoliko in nejasno kot pojem sam. ${ }^{1}$ To pomeni, da je časovno zamejevanje romantike predvsem odvisno od razumevanj in razlag pojma, ki lahko postanejo morebitna osnova periodizacijski kategoriji.

Nedvomno je, da pojma romantična glasba in glasbena romantika še danes predstavljata v zavesti glasbenikov glasbo 19. stol., pri tem pa nemalokrat postavljajo enačaj med glasbo 19. stol. in romantiko kot glasbenozgodovinskim obdobjem. Tovrstnega pojmovanja niso 'zakrivili' izključno številni glasbenozgodovinski pregledi v 20. stol., ki so 19. stol. označevali kot glasbeno romantiko ali romantično glasbo, temveč tudi dejstvo,

1 Hans Heinrich Eggebrecht. 'Romantisch, Romantik'. V: Handwörterbuch der musikalischen Terminologie. Albrecht Riethmüller (ur.) Zv. V: P-Se. Stuttgart: Franz Steiner Verlag, 1999, 9. 
da sodobna muzikološka veda ni ponudila terminološke fiksacije pojma.

Glasbenozgodovinski pregledi prve polovice 20. stol. uporabljajo pojem romantika kot skupno oznako, ki združuje različne glasbeno-kulturne pojave 19. stol. in kot taka postaja oznaka za glasbenozgodovinsko obdobje. ${ }^{2}$ Nekritični prenos kategorije kot obdobja v glasbenozgodovinske preglede je pomenil le navidezno ureditev in periodizacijo izrazito heterogenega časa, ki ga je povezovala zgolj oznaka obdobja. ${ }^{3}$ Razlog za takšno stanje je tičal tudi v tem, da se je termin romantika v glasbeni zgodovini kot izrazito znanstveni pojem uveljavil šele v drugi polovici 20. stol. Tako romantika kot oznaka za glasbenozgodovinsko obdobje predstavlja v glasbenozgodovinskih pregledih prve pol. 20. stol. neredko zgolj nalepko, torej periodizacijsko sredstvo, ki združuje najrazličnejše pojave, sama kot taka pa najpogosteje ne pove ničesar.

Poskus znanstvene opredelitve pojma so prinesle šele muzikološke razprave druge polovice 20. stol., ki so se spopadale tudi s poskusom definiranja določitve romantike kot glasbenozgodovinskega obdobja. Seveda pa je to odvisno predvsem od načina interpretacije romantike kot glasbenozgodovinskega pojma.

Izbor razprav bo skušal pokazati, v kolikšni meri je muzikološka veda uspešno definirala periodizacijo romantike kot glasbenozgodovinske oznake. Tako Friedrich Blume meni, da je v kontekstu glasbene zgodovine romantiko mogoče razumeti le kot delni pojav znotraj enovitosti klasicistično-romantične dobe. ${ }^{4}$ Torej klasicizem in romantika kot glasbenozgodovinski obdobji sestavljata po njegovem celoto. "Sta dva aspekta istega glasbenega pojava in istega zgodovinskega obdobja. Znotraj tega pojava in te dobe, in sicer od začetka do postopnega izteka v 20. stol., je obstajal enkrat bolj klasični, drugič bolj romantični tok. Ni ju mogoče klasificirati, ker sta zavezana osebnostim, smerem, modam in namenom. ${ }^{5}$ Pravi, da so temeljne naloge in težnje ostale enake, prav tako temeljni nazori o bistvu glasbe kljub bolj ali manj odločilnim nasprotnim, vzporednim, stranskim nazorom. Zato "romantični stil« kot določljiv in zamejen ne obstaja sam zase. Obstaja le "počasna preobrazba tistega stilnega tipa, ki se je na začetku klasično-romantične dobe izoblikoval in se od takrat razvijal, stopnjeval, postajal kompleksen in se ne nazadnje potem razkrojil ${ }^{6}$ Blume je prepričan, da so začetki

2 Recepcija pojma v 19. stol. kaže na njegovo pomensko heterogenost in večplastnost, saj je bil uporabljen v najrazličnejših kontekstih in na najrazličnejših miselnih ravneh. Prim.: Martin Wehnert. 'Romantik und romantisch'. V: Die Musikin Geschichte und Genenwart. Allgemeine Enzyklopädie der Musik. Ludwig Finscher (ur.) Zv. 8. Kassel: Bärenreiter, 1998, 470-474. - Ulrich Tadday. Das schöne Unendliche. Stuttgart, Weimar: Verlag J. B. Metzler, 1999, 203-218. - Hans Heinrich Eggebrecht. 'Romantisch, Romantik'. V: Handwörterbuch der musikalischen Terminologie. Albrecht Riethmüller (ur.) Zv. V: P-Se. Stuttgart: Franz Steiner Verlag, 1999, 1-9.

Že v drugi polovici 19. stol. je bil izraz romantika oznaka za glasbenozgodovinsko obdobje. Čeprav so glasbene zgodovine poznega 19. stol. obdobje 'romantike' sicer in širjenja na vedno poznejši čas opazovale tudi s kritičnimi pridržki, se je ob prelomu stoletja uveljavilo pozitivno prevrednotenje pojma v korist opazovanja neposredno preteklega časa kot romantičnega glasbenozgodovinskega obdobja. Prim. U. Taddy, nav. delo, 207-209.

3 Prim.: Ernst Bücken. Die Musik der 19. Jahrhunderts bis zur Moderne. Wildpark-Postdam: Akademische Verlagsgesellschaft Athenaion M.B.H., 1929, 20-26. Bücken ločuje med romantičnim in romantiko. Prvo zanj predstavlja duhovno držo, drugo pa glasbenozgodovinsko obdobje. - Paul Henry Lang. Music in Western Civilization. New York: W. W. Norton \& Company, Inc., 1941. - Kurt Pahlen. Musikgeschichte der Welt. Zürich: Orell Füssli Verlag, 1947, 216-220. - Frizt Högler. Geschischte der Musik. Wien: Osterreichischer Bundesverlag, 1949, 101-106.

4 Prim. Friedrich Blume. 'Romantik'. V: Die Musik in Geschichte und Gegenwart. Allgemeine Enzyklopädie der Musikwissenschaft. Friedrich Blume (ur.) Zv. 11. Kassel: Bärenretier, 1963, 758-845.

5 Prav tam.

6 Prav tam. 
velikih glasbenozgodovinskih obdobij določljivi z opazovanjem nastajajočega novega in abstrahiranjem starega. Vendar pa je zaključke le-teh precej težje definirati, saj »vsako še obstaja znotraj naslednjega«. Romantika ni izoblikovala drugačnega in samostojnega stila, temveč je zgolj razvila omenjeni »visoko klasični tip «. ${ }^{7}$ Ob tovrstni opredelitvi izhaja Blume iz ugotovitve, da romantika ni stil, ki bi ga lahko definirali, temveč zgolj duhovna drža. Ta se kaže predvsem v refleksijah o glasbi, torej romantični glasbeni estetiki. Celo klasicistično-romantično obdobje zamejuje kot celoto nasproti prejšnji dobi - baroku - in novi glasbi, ki je sledila, to pa pomeni, da govorimo o obdobju, ki obsega čas med nekako 1760. in prvim desetletjem 20. stol. Tako Beethoven predstavlja zanj zgolj eno od številnih vmesnih postaj.

Izhodišče, ob katerem gradi Blume svoje pojmovanje enotnosti klasicističnoromantičnega obdobja, je kanon oblik. Nasproti različnim težnjam v 19. stol. zagotavlja ta obdobju določeno enovitost. Vendar pa - čeprav opredeljuje romantiko kot duhovno držo in zagovarja enotnost klasicistično-romantičnega obdobja - v svoji razpravi podaja prikaz glasbene zgodovine 19. stol. v kontekstu posameznih kompozicijskih prvin. ${ }^{8}$ Ta dihotomija med razumevanjem glasbenozgodovinskega prikaza in obdobja lahko nakazuje bodisi zasidranost ustaljenih prepričanj, ki jih obvladuje močna zgodovinska zavest in onemogoča, da bi pozabili na tradicionalne časovne določitve romantike, bodisi Blumejevo negotovost pri opredeljevanju pomena romantike.

Rey M. Longyear govori o »ustaljeni navadi«, da romantika predstavlja glasbenim zgodovinarjem glasbo med 1828. in 1880. v najožjem ter med 1789. in 1914. v najširšem pomenu besede. Pravi, da je navada njegovega časa razumeti klasicizem in romantiko kot nasprotni strani istega kovanca, to pa pomeni v najožjem pomenu besede čas med 1740. in 1830., v najširšem pa do 1910. Tovrstna opredelitev po Longyearovem mnenju po eni strani izključuje raziskovanje vseh 'pre-'. 'post-' in 'neo' predpon, po drugi pa ne upošteva novih teženj v tem devetdeset do sto sedemdeset let trajajočem obdobju. ${ }^{9}$ Čeprav se zaveda, da je romantika problematična oznaka za obdobje, se ji v svoji razpravi ni odpovedal. Pravzaprav, kot je vidno že iz samega naslova knjige, pojmuje Longyear celotno 19. stol. kot obdobje romantike, a ga diferencira po posameznih tematskih naslovih. ${ }^{10}$ Tako bi lahko dejali, da Longyearov glasbenozgodovinski oris označuje kot predhodnika romantike v glasbi čas gibanja Sturm und Drang in celotno Beethovnovo ustvarjalnost; Beethovnovih sodobnikov, torej tistih, katerih glasbena ustvarjalnost je doživela razcvet med 1830. in 1850., pa ni apostrofiral neposredno kot romantične, temveč kot progresivne skladatelje. Svojo razpravo in s tem tudi obdobje romantike končuje (če ne upoštevamo francoskih skladateljev ob prelomu stoletja) z Mahlerjevo in Straussovo glasbo. Pravi, da je Mahler s svojo peto simfonijo "prestopil iz romantike 19. stol. v post- ali hiperromantiko 20. stol.«. ${ }^{11}$

7 Avtor obravnava te prvine: 1 . ritem, metrum, tempo, 2. harmonija in tonaliteta, 3. motiv, tema in tematsko delo, 4. zvrsti in oblike. Prav tam, 806-831.

8 Longyear trdi, da so vse oznake obdobij udobnosti in da se uporabnost giblje v razmerju do truda, porabljenega za definiranje le-teh ali postuliranje odnosov med kulturnimi, intelektualnimi, socialnimi in zgodovinskimi komponentami. Rey M. Longyear. Nineteenth-Century Romanticism in Music. Engelwood Cliffs, New Jersey: Prentice-Hall, 1969, 2.

9 Tako govori o Beethovnu in njegovih predhodnikih, Beethovnovih sodobnikih, razcvetu nemške romantike, italijanski in francoski romantiki, glasbi prihodnosti (vključuje Liszta in Wagnerja), govori o ponovnem rojstvu absolutne glasbe, nacionalizmu 19. stol. v glasbi ter o izzvenevanju romantike.

10 Longyear, prav tam, 192-193.

11 Longyearu prav tako ne nasprotuje diferenciaciji obdobja z rabo oznake "post-romantikak. 
Torej začetek obdobja romantike posredno nakazuje Beethovnova umetnost, vključuje vse izstopajoče glasbene osebnosti 19. stol., končuje pa prehod v 20. stol. Romantika v glasbi je zanj stilno poenotena zgodovinska entiteta, v kateri pa izstopajo posamezne usmeritve, generacije in individualne osebnosti skladateljev. ${ }^{12}$

V definiciji romantike Johna Warracka najdemo časovno zamejevanje obdobja na čas med približno 1790. in 1910. ${ }^{13}$ Zdi se, da obe letnici prevzema iz obstoječih glasbenozgodovinskih razprav, kajti Warrack se ne obremenjuje s poskusom utemeljevanja legitimnosti in trajanja obdobja. Zanj je romantika "gibanje v umetnosti in misli«, ki je vplivalo na celotno glasbeno ustvarjalnost 19. stol. Po njegovem mnenju je gibanje doseglo vrhunec prav z Wagnerjevo umetnostjo in je po skladateljevi smrti, letu 1883, kljub delu »velikih poznoromantičnih skladateljev, zlasti Mahlerja« oslabelo. ${ }^{14}$ Iz Warrackovega pojmovanja romantike lahko razberemo razumevanje obdobja kot glasbenozgodovinske oznake za celo 19. stol.

Naslov razprave Leona Plantinge »Romantična glasba« s podnaslovom »Zgodovina glasbenega stila v Evropi 19 .stol." sugerira razumevanje glasbe 19. stol. z zbirnim imenom 'romantično'. Nikjer v razpravi Plantinga ne opredeljuje natančneje, ali ob tem razume tudi obdobje. Vendar v uvodu podaja misel, da »smo doslej že na nekaj mestih v razpravi uporabljali pojem 'romantično' kot splošno oznako za prevladujoče poteze glasbe 19. stol. Koncepti in imena kot je to bodisi za opisovanje stila, kanone okusa bodisi označitev dobe so otopeli inštrumenti, katerih pomanjkljivosti so bile že poudarjene $\ll{ }^{15} \mathrm{~S}$ to mislijo se Plantinga sicer na videz distancira od opredeljevanja romantike kot glasbenozgodovinske dobe, vendar pa se mu ni mogel izogniti pri zamejevanju zgodovinskega časa, ki ga interpretira glasbenozgodovinski pregled. Svojo razpravo začenja z letnico 1792 oz. Beethovnovim odhodom na Dunaj, končuje pa s Straussovimi simfoničnimi pesnitvami in Mahlerjevimi prvimi tremi simfonijami. Razprava tako obsega čas do začetka 20. stol., pri čemer je Mahlerjeva simfonična ustvarjalnost postavljena v dve ločeni glasbenozgodovinski 'obdobji' ${ }^{16}$ Tudi izbira letnice 1792 se zdi poleg vseh drugih potencialnih letnic nekako izbira, ki jo je mogoče interpretirati s tradicionalnim zamejevanjem romantike. Kot je že Longyear dejal, predstavlja romantika v najširšem pomenu besede glasbenim zgodovinarjem obdobje med 1789. in 1914. Obe letnici nakazujeta bolj sočasnost s politično kot kulturno zgodovino. Zdi se, da Plantingova odločitev pri zamejevanju začetka romantike skuša poiskati letnico, ki ne bi bila preveč oddaljena od francoske revolucije.

Beethovnove umetnosti ne označuje za romantično, vendar tudi v nadaljevanju ne govori o romantičnih skladateljevih ali pa romantični generaciji skladateljev. Iz tega izhaja, da je zanj obdobje romantike zgolj nalepka za določen oz. predstavljen glasbenozgodovinski čas in nikakor ne problemsko področje, ki bi mu bilo treba pripisati kakršenkoli pomen.

12 John Warrack. 'Romantic'. V: The New Grove Dictionary of Music and Musicians. Stanley Sadie (ur.), Zv. 16. London: Macmillan, $1980,141$.

13 Prav tam, 144.

14 Leon Plantinga. Romantic Music: A History of Musical Style in Nineteenth-Century Europe. New York, London: W. W. Norton \& Co., 1984, 20.

15 Ta razdelitev je vsekakor vprašljiva.

16 Donald Jay Grout, Claude V. Palisca. A History of Wstern Music. New York. London: W. W. Norton \& Co., $1988,656-657$. 
Razprava Zgodovina zahodne glasbe Donalda Jaya Grouta in Claudea V. Palisce se je zaradi vsebinske zasnove glasbenozgodovinskega pregleda izognila vprašanju romantike kot glasbenozgodovinskega obdobja. Avtorja obravnavata 19. stol. po glasbenih zvrsteh, kljub temu pa sta v uvodu h glasbi 19. stol. napisala: "več ko o glasbi določenega časa, prostora ali pa skladatelja vemo, vedno bolj nam postaja jasno, da so posplošeni opisi stilov neprimerni, meje obdobij pa samovoljno postavljene. Kljub temu pa je delitev glasbene zgodovine na stilna obdobja uporabna. Periodizacija upravičuje tako kontinuiteto kot spremembe. Nalepki klasika in romantika sta približni in netočni, lahko sta le orientacijski točki v pristopu do dejanske glasbe ${ }^{17}{ }^{17} \mathrm{~V}$ devetnajstem poglavju razprave z naslovom Konec dobe omenjata, da je bila zadnja tretjina 19. stol. razmeroma mirna in stabilna, da pa začetek 20. stol. označuje povečevanje »splošnega nezadovoljstva družbe in mednarodne napetosti, ki je doseglo vrhunec prav s prvo svetovno vojno ${ }^{18}$ Nemir in napetosti naj bi se na glasbenem področju manifestirali v »različnih radikalnih eksperimentih«. In prav v tem času naj bi se po njunem mnenju sklenila klasicistično -romantična doba in z njo konvencije tonalnosti, značilne za glasbo 18. in 19. stol. Že sam naslov poglavja namiguje na konec dobe, ki jo, kot se v nadaljevanju izkaže, avtorja razumeta kot klasicistično-romantično dobo. S tem se ne le približujeta Blumejevi tezi o enovitosti klasicistično-romantične dobe, temveč izhajata iz predpostavk tonalnosti in kanona oblik, ki omenjeni glasbenozgodovinski čas kontinuirano združujeta.

Dahlhaus je zavrgel tradicionalno pojmovanje romantike kot oznake za zaključeno dobo med klasicizmom in novo glasbo. Meni, da je ta klišejska predstava, ki združuje vse (pomembne in nepomembne) skladatelje od Schuberta do Mahlerja v en zbirni pojem ali pa v pojem glasbenozgodovinskega obdobja, napačna. ${ }^{19}$ Da bi kategorija lahko postala uporabna tudi kot oznaka za glasbenozgodovinsko obdobje, bi jo bilo po njegovem mnenju potrebno precizirati.

Dahlhausova kritika nedvomno izhaja iz nekritične rabe pojma v dotedanjem glasbenem zgodovinopisju. Narobe bi bilo razumeti, da Dahlhaus predlaga ukinitev glasbenozgodovinskega pojma in s tem tudi oznake za glasbenozgodovinsko obdobje. Dahlhaus zgolj opozarja na relativnost pomena pojma, ki je ob nereflektirani in nekritični rabi v glasbenem zgodovinopisju postal zgolj nalepka, ki poleg tega, da obstaja, ne pove ničesar, ali pa so njegove interpretacije tako heterogene, da so glasbenemu zgodovinopisju vse prej kot v oporo. V svoji razpravi, ki sprva namiguje na ukinitev rabe pojma, vendar v nadaljevanju pretresa uporabnost le-tega ter skuša nanovo vzpostaviti vrednostne kriterije, po katerih bi le-ta lahko postal uporaben, ne preverja romantike kot pojma za glasbenozgodovinsko obdobje. Na ta segment posredno odgovarja v razpravi 'Neoromantika', ki bo omenjena v nadaljevanju.

Nadaljnja kritika rabe pojma kot oznake za glasbenozgodovinsko obdobje je v razpravi Romantika v glasbi Petra Rummenhöllerja. Rummenhöller opozori na ustaljeno rabo v glasbenem zgodovinopisju in tudi govorni rabi, po katerih je romantika splošno glasba 19. in začetka 20. stol, torej nekako od Carla Marie von Webra do Rich-

17 Prav tam, 755.

18 Carl Dahlhaus. 'Musik und Romantik'. V: Die Musik des 19. Jahrhunderts. Wiesbaden: Athenaion, Laaber: Laaber, $1980,13$.

19 Peter Rummenhöller. Romantik in der Musik. Analysen, Portraits, Reflexionen. München: Deutscher Taschenbuch Verlag, 1989, 8-9. 
arda Straussa. ${ }^{20} \mathrm{Ob}$ tem izpeljuje primerjavo z literarno romantiko, za katero ugotavlja, da je »velikodušno računano« trajala 35 let (v obdobju med letoma 1800 in 1837). Tako se mu zdi 140 let glasbene romantike glede na 35 let literarne romantike "pošastno« dolgo. Dodaja, da konec enega fenomena pravzaprav predstavlja šele pravi začetek in polni čas delovanja drugega. Rummenhöller meni, da je romantika kot pojem za glasbenozgodovinsko obdobje neenotna in zato tudi neuporabna. Od tod je izpeljal ugotovitev, da romantika (v glasbi) ni oznaka za obdobje, temveč zgolj svetovni nazor. Pravi, da je treba, če želimo romantiki in romantičnemu povrniti smisel, njun pomen in rabo radikalno omejiti na določen čas. V svoji razpravi zato govori zgolj o glasbi prve polovice 19. stol., pri tem pa ne označuje vse takratne glasbe za romantično. Rabo pojma kot oznake za glasbenozgodovinsko obdobje je nadomestil z interpretacijo o romantični generaciji skladateljev. Kot pravo romantično generacijo skladateljev označuje »rojene okoli 1. 1810«: Mendelssohna (1809), Schumanna in Chopina (1810) ter Franza Liszta (1811). Ob tem pripominja, da je Liszt »znatno prestopil prag sredine stoletja« in da kot skladatelj simfoničnih pesnitev ne more pripadati več romantiki. Kot izhaja iz navedenega, enači Rummenhöller romantiko z romantično generacijo skladateljev, pri tem pa pojem definira kot delni fenomen $\mathrm{v}$ glasbi prve polovice 19.stol.

Tako je romantiko v glasbi po njegovem mogoče zaslediti v delih omenjenih skladateljev v času med 1830. in 1850. Čeprav se Rummenhöller vnaprej odpove možnosti uporabe pojma kot glasbenozgodovinske oznake, pa vendarle v svoji razpravi posredno uporablja periodizacijo 'fenomena'. Trajanje le-tega je določil na osnovi generacijskega vidika. Pri tem je upošteval letnice rojstva skladateljev in njihovega vstopa v javno glasbeno življenje ter ob izbranem glasbenem gradivu prepoznaval pripadnost le-tega romantiki, kot izhaja seveda iz njegove literarne interpretacije pojma. Čeprav ugotavlja, da skladatelji po letu 1850 uporabljajo nekatere "romantične pridobitve«, pa časa po 1850 nikakor ne želi označiti kot romantičnega. ${ }^{21}$

Generacijski vidik 'periodizacije' uporablja tudi Charles Rosen v svoji razpravi »Romantična generacija«. Razprava je omejena na čas med letoma 1827 in 1849, letnici pa je določil glede na leto Beethovnove in Chopinove smrti. Rosen meni, da naj bi Beethovnova smrt pospešila razvoj novih stilnih tendenc v ustvarjalnosti skladateljev rojenih »okoli 1810 « ${ }^{22}$ Ugotavlja, da le Chopina ni prestrašila impozantna podoba avtoritete, ki naj bi jo Beethoven utelešal mlajšim generacijam skladateljev. Chopinova smrt bi po Rosenu lahko pomenila konec enega obdobja, saj je Schumann umrl nekaj let za njim, Liszt pa se je po letu 1850 odpovedal »mnogim smelim prijemom in razvil nove poti v glasbenem stilu «. ${ }^{23}$ Leta 1850 prihaja na glasbeno sceno mladi Brahms, katerega ustvarjalnost je nakazala, da je »bila v zraku nova in bolj konzervativna glasbena filozofija ${ }^{24}$ Rosen se je v svoji razpravi omejil na tiste skladatelje, katerih "značilni stili so bili definirani konec dvajsetih in ob začetku tridesetih let 19. stol.«, in katerih glasba je bila "nedvoumno povezana z umetnostjo, literaturo, politiko in osebnim življenjem

20 Rummenhöller navaja, da literarna zgodovina označuje čas, ki je sledil romantiki, kot "poetični realizem in da bi njegovo uporabnost veljalo preveriti tudi v glasbenem zgodovinopisju. Prav tam, 11.

21 Charles Rosen. The Romantic Generation. Cambridge (Massachusetts): Harvard University Press, 1995 , IX.

22 Prav tam.

23 Prav tam, IX-X.

24 Prav tam, X 
na način, ki je bil sicer manj neposreden in bolj ambivalenten kot v glasbi predhodnih obdobij ${ }^{25}$

Tako Rummenhöller kot Rosen povezujeta romantiko v glasbi ali 'romantični' čas v zgodovinopisju z generacijo skladateljev rojenih »okoli 1810«. Razlika je v tem, da prvi upošteva že letnico 1810, drugi pa čas njihove ustvarjalne uresničitve v javnem življenju. Pri obeh se omenjeni čas sklene na polovici stoletja. Avtorja ne zamejujeta 'romantičnega' časa z letnicami, ki bi iskale vzporedje z odločilnimi letnicami literarne ali pa politične zgodovine. Kot novost pri obeh se izkaže zamejevanje 'fenomena' na opazno krajše časovno obdobje, kot ga je glasbeno zgodovinopisje dotlej opredeljevalo. Oba govorita o novem času v glasbeni zgodovini po letu 1850, ki pa ga natančneje ne opredelita. Torej romantiko v glasbenem zgodovinopisju povezujeta z ustvarjalnostjo skladateljev prve polovice 19. stol., natančneje z (romantično) generacijo skladateljev rojenih okoli 1810. Kot kriterij pripadnosti le-tej pa navajata značilnosti glasbenega jezika. Pojem romantika kot oznaka za glasbenozgodovinsko obdobje Rummenhöller je zavrgel, Rosen pa se mu je izognil. Kljub temu razpravi temeljita na periodizaciji, katere izhodišče predstavlja generacijski vidik.

Rummenhöllerjeva in Rosenova interpretacija periodizacije 'romantike' v glasbi posredno upošteva Dahlhausove ugotovitve in periodizacijo 'neoromantike' v glasbenem zgodovinopisju. Dahlhaus ne govori o času, o katerem pišeta Rummenhöller in Rosen, razpravlja pa o poskusu interpretiranja glasbenozgodovinskega časa po letu 1850. S svojo razpravo se torej zelo posredno dotika prve polovice 19. stol. in v luči razumevanja glasbenozgodovinskega časa druge pol. 19. stol. sugerira odnos do interpretiranja prve polovice stoletja. Kot sta ugotovila že Rummenhöller in Rosen, je glasba druge pol. 19. stol. »neromantična" (Rummenhöller) oz. "pripada naslednji generaciji skladateljev« (Rosen). Dahlhausova interpretacija glasbenozgodovinskega časa po letu 1850 izhaja iz zgodovinskofilozofske ali duhovnozgodovinske perspektive razumevanja tega obdobja. Za glasbo prve pol. 19. stol. pravi, da je »romantična v času romantike, ki je ustvaril tudi romantično poezijo in slikarstvo, neoromantika druge pol. 19. stol. pa je bila romantika v neromantičnem času, v katerem sta dominirala pozitivizem in realizem «. ${ }^{26}$ Dahlhaus meni, da se je v prvi pol. 19. stol. filozofija imela za bistvo znanosti, umetnost pa je bila prežeta z metafizičnim dostojanstvom. ${ }^{27}$ Toda pozitivizem druge pol 19. stol. ni veljal za trivialno realnost, ki bi mu filozofija in umetnost lahko nasprotovali in s tem predstavljali pravo realnost. Prav tako ni bil zgolj nasprotje duhovnim, intelektualnim in kulturnim težnjam časa, temveč je bil sam kot tak duh znanstvene dobe. ${ }^{28}$ Tako se je glasba v tem novem času ločila od duha dobe in prav ta ločitev ji je omogočila izpolnjevanje duhovne, kulturne in ideološke funkcije, ki pa »se je zavzemala za alternativni svet«. Tudi sama trditev "glasba je drugačna« je predstavljala jedro glasbene estetike dobe pozitivizma. ${ }^{29}$ Če so bile ideje, s katerimi je bila glasba prežeta v prvi pol. 19. stol., sorodne principom, ki so bili prevladujoči v literaturi, slikarstvu in filozofiji, pa to ne velja več za čas po 1850. Glasba je postala v času, ki je vedno bolj reflektiral metodologijo naravoslovnih znanosti,

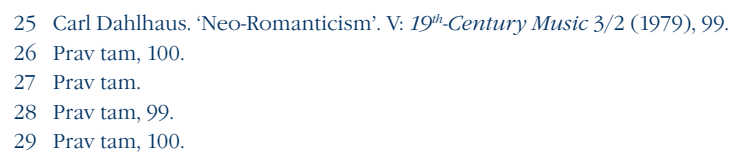


presežena in s tem tudi izolirana umetnost. ${ }^{30}$ Dahlhaus ugotavlja, da je prav s tem da je omogočala alternativo realnostim sveta po eni strani povečala svoj vpliv, po drugi pa zaradi odtujitve od pozitivističnega duha časa ni mogla veljati za »reprezentativno« umetnost, tj. dokument in refleksijo svojega časa. Dahlhaus utemeljuje razumevanje razmerja romantika - neoromantika na osnovi duhovnozgodovinske interpretacije, $\mathrm{v}$ kateri poudarja prepad med glasbo ter sočasno literaturo in umetnostjo. Čeprav je po njegovem mnenju glasba druge pol. 19. stol. še vedno romantična, vendar 'odmaknjena' od sočasnega duha časa, pa ne pomeni, da po 1850. tudi sama ni bila deležna strukturnih sprememb. Kot je vidno iz razprave, Dahlhaus ne išče neposrednih analogij med političnimi in filozofskimi gibanji časa s sočasno glasbo. S tem da je obdobje neoromantike postavil med letnici 1850 in 1890 (ali 1910), pri ‘izbiri' letnic ni imel v mislih ne odločilnih ne glasbenih dogodkov, temveč dejstvo, da se je v tem času zgodil »duh kulturnega prevrednotenja«, ki pa je nedvomno vplival na mišljenje o glasbi in tudi na glasbo samo. Iz tega lahko sklepamo, da neoromantika kot oznaka za glasbenozgodovinsko obdobje ne predstavlja Dahlhausu zgolj duhovnozgodovinskega konteksta glasbe v pozitivističnem duhu časa, temveč tudi spremembo, ki jo je glasba manifestirala v sebi sami, zlasti na področju jezika struktur.

Čeprav se Dahlhaus z vprašanjem tega ne ukvarja, pa s svojo interpretacijo razumevanja in razčlenjevanja 'dobe' lahko predstavlja argument in potrditev izsledkov novejših raziskav, zlasti Rummenhöllerjevo in Rosenovo periodizacijo 'romantike' v glasbi.

Pri poskusu interpretacije romantike kot glasbenozgodovinskega obdobja opazuje Martin Wehnert romantiko v luči stilnega obdobja. Meni, da se je sistem členjenja stilnih obdobij v zgodovini umetnosti, ki ga je z upoštevanja vrednimi rezultati prevzela tudi muzikologija, pokazal za plodovitega. ${ }^{30}$ Vendar pa je proces individualiziranja in diferenciranja pripeljal do situacije, v kateri se je romantična duhovna drža v potencirani obliki pokazala za preveč odprto. ${ }^{31}$ Ugotavlja, da je 19. stol. "globoko raztrgano stoletje« ter izpeljuje, da je razpravljanje o romantični dobi v 19. stol. contradictio in adjecto. Ob romantiki 19. stol. prepoznava Wehnert še neromantike, tj. »alternativne« pojme (bidermajer, realizem, klasicizem, historicizem, nacionalne romantike in neoromantie), na osnovi katerih je zavrgel prepričanje o stilni enotnosti 19. stol. in jo nadomestil s stilnim pluralizmom. Wehnert uporablja sintagmo Walterja Wiore, iz katere izhaja dvojna vloga muzikologije: "po eni strani kritika na račun mnenja o domnevni enotnosti [romantike], po drugi pa raziskovanje, ali obstajajo skupne značilnosti in kako daleč te segajo «. ${ }^{32}$ Mnenja je, da je ta postulat potrebno imeti »še danes« za nerešenega. Torej Wehnert postavlja domnevni romantiki kot pendant alternativne pojme, s katerimi je ovrgel možnost razpravljanja o romantiki kot morebitnem glasbenozgodovinskem obdobju. Pravzaprav se je temu vnaprej odrekel. Vendar pa se ob njegovem zagovoru stilnega pluralizma postavlja vprašanje, ali so alternativni pojmi, ki jih navaja kot argument za razpad stilne enotnosti, aktualni tudi v glasbi prve pol. 19. stol. Prav tako se poraja pomislek, ali so 'alternative' odločilno zaznamovale glasbena dela druge pol. 19. stol.

\footnotetext{
30 Martin Wehnert. 'Romantik und romantisch'. V: Die Musik in Geschichte und Genenwart. Allgemeine Enzyklopädie der Musik. Ludwig Finscher (ur.) Zv. 8. Kassel: Bärenreiter, 1998, 491.

31 Prav tam.

32 Prav tam, 492
} 
Če parafraziram Carla Dahlhausa, ki pravi, da definicije obdobja v zgodovini umetnosti ali katerikoli drugi umetnosti niso nikoli povsem neodvisne od vrednostnih presoj, lahko rečem, da iskanje skupnega imenovalca vse glasbe, nastale v 19. stol., predstavlja zmotno predstavo o razumevanju umetnostnozgodovinskega ali glasbenozgodovinskega obdobja. Wehnertovo razumevanje obdobja izhaja iz stilne enotnosti, ta pa domnevno iz načina razumevanja klasicizma kot stilno enotne dobe, katere model stilne enovitosti skuša prepoznati Wehnert tudi v glasbi 19. stol. Vprašanje, ali pojmovanje romantike lahko utemeljujemo na podlagi predpostavk razumevanja obdobja glasbenega klasicizma, predstavlja tisti odgovor, ki bi lahko omogočil poskus morebitnega ponovnega definiranja romantike kot glasbenozgodovinskega obdobja. Tako postane razumljivo tudi izhodišče Wehnertovega zanikanja romantike kot glasbenozgodovinskega obdobja.

Da poskus definiranja glasbenozgodovinskega obdobja na podlagi stilne enovitosti ni najbolj varna osnova za morebitno določanje obdobja romantike, je opozoril Jim Samson. Tovrstni 'nevarnosti' se je izognil tako, da je predlagal obravnavanje romantike predvsem glede na »ideje in spodbude« in manj glede na glasbene stile. ${ }^{33}$ Če pa bi se odločili za to možnost, sugerira »omejevanje pojma na opis večjih tendenc, izvirajočih iz tistih idej in spodbud, ki bi se jih lahko uporabilo za celotno obdobje ${ }^{34} \mathrm{~V}$ svoji razpravi Samson ne želi natančneje opredeliti lastnega stališča glede romantike kot glasbenozgodovinskega obdobja. V uvodni definiciji označuje romantiko kot gibanje ali obdobje kulturne zgodovine, ki se identificira bodisi s prvo polovico 19. stol. bodisi s celotnim 19. stol. Vendar pa je iz načina njegovega nadaljnjega razpravljanja o romantiki vidno, da mu je bilo bližje razumevanje obdobja v blumejevskem kontekstu periodizacije kot pa zamejevanje obdobja na polovico stoletja. Ob tem navaja tendence, ki so po njegovem mnenju navzoče v glasbi vse do prehoda v 20. stol.

Romantika je v glasbenozgodovinskih pregledih prve pol. 20. stol. predstavljala zgolj nalepko, torej imenovalec, ki naj bi brez jasne osnove združeval najrazličnejše pojave v 19. stol., razprave druge pol. 20. stol. pa so preverile dejansko uporabnost te nalepke. Kritični vpogled v rabo pojma je omogočil stabiliziranje pomena in vzpostavitev njegove (ne) uporabnosti. Kategorija, ki je še v nekaterih glasbenozgodovinskih pregledih in razpravah druge pol. 20. stol. veljala za samoumevno, je postopoma zahtevala znanstveno opredelitev.

Izbira navedenih diskurzov, ki se dotikajo tudi vprašanja periodizacije romantike in s tem (nekatere) skušajo opredeliti ali opredeljujejo le-to kot glasbenozgodovinsko obdobje, je pokazal, da sta se v drugi pol 20. stol. in začetku 21. stol. izoblikovala dva modela interpretiranja pojma kot glasbenozgodovinsko razumljenega obdobja: prvi je blumejevsko zamejevanje romantike, po katerem se romantika neposredno navezuje na klasicizem oz. z njim sestavlja zaprto celoto, kar pomeni da traja vse od druge pol. 18. pa do začetka 20. stol.; drugi in hkrati novejši zagovarja tezo, da o romantiki lahko govorimo le v prvi pol. 19. stol. Čeprav se zdi, da Blumejeva periodizacija na nek način ponavlja ustaljeno prakso označevanja celotnega 19. stol. kot romantičnega, je novost v tem, da Blume podaja argumente v dokazovanju pojma kot glasbenozgodovinskega

33 Jim Samson. 'Romanticism.' V: Grove Music Online. Oxford Music Online, http://www.oxfordmusiconline.com/subscriber/ article/grove/music/23751 (dostop 22. marec 2007).

34 Prav tam. 
obdobja. Njegova periodizacija temelji na spoznanju, da strukturne in oblikovne osnove 18. stol. ostanejo prisotne tudi v glasbi 19. stol. Torej, kanon oblik je tista predpostavka, ki zagovarja enotnost klasicistično-romantičnega obdobja. Zanimivo je, da Blumejeva trditev iz 60. let 20. stol. še danes predstavlja nekaterim glasbenim zgodovinarjem izhodišče pri zamejevanju tega glasbenozgodovinskega obdobja. Lahko bi celo dejali, da je postblumejevski diskurzi definiranja tega glasbenozgodovinskega obdobja niso nikoli povsem ovrgli ali pa zanikali. Tisto, kar ponuja drugi model zamejevanja glasbenozgodovinskega obdobja, predstavlja na določen način konkretizacijo in diferenciacijo obstoječe blumejevske paradigme, ki pa je pripeljala do nekaterih novih spoznanj. Novejše raziskave zagovarjajo interpretacijo romantike kot oznake za glasbenozgodovinski čas le v prvi pol. 19. stol., pri čemer pravzaprav nikakor ne želijo govoriti o zaprtem obdobju, temveč o romantični generaciji skladateljev. To ne izhaja toliko iz obstoječe kritike rabe pojma in zato previdnosti rabe le-tega, temveč spoznanja, da je generacija skladateljev, rojenih okoli 1810., ne le iz konteksta novih družbenih, filozofskih, kulturnih in sploh intelektualnih premen zaznamovala nov čas v zgodovini glasbe, temveč je s svojo ustvarjalnostjo ponudila tudi novosti v samih strukturah kot jeziku le-teh. Drugi model je vzpostavil ločnice tako med glasbo poznega 18. stol. in glasbo romantične generacije skladateljev, kot tudi med slednjimi in skladatelji druge pol. 19. stol. Po tej plati je pokazal, da kljub kanonu zvrsti obstajajo mehanizmi, ki paradigmo o enotnosti klasicistično-romantične dobe ali pa celotnega 19. stol. lahko znanstveno na novo preverijo in omogočijo vzpostavitev novega in tudi drugačnega razumevanja tega glasbenozgodovinskega časa. Mlajše razprave (Dahlhaus, Rummenhöller, Rosen) so enotne pri upoštevanju dejstva, da je raba pojma v glasbenem zgodovinopisju primerna za čas prve pol. 19. stol. Čeprav tega časa ne želijo označiti kot obdobje v glasbeni zgodovini, temveč ga argumentirajo z generacijskim vidikom, lahko ta postane osnova za morebitno nadaljnje razpravljanje bodisi v zagovor bodisi kritiko rabe pojma kot oznake za glasbenozgodovinsko obdobje.

Pričujoča razprava želi izpostaviti še en premislek, ki ga je spodbudilo Wehnertovo enačenje romantike $z$ enotnostjo stila. Ob tem se postavlja vprašanje, ali je enotnost stila pogoj za obstoj glasbenozgodovinskega obdobja. Če je, je romantika kot glasbenozgodovinsko obdobje vnaprej obsojena na zanikanje, to pa se kot posledica dotika tudi interpretiranja romantične generacije skladateljev. Tako znameniti stavek Walterja Wiore »romantika je smrt stila« lahko beremo na dva načina: da romantiko želimo (tudi kot obdobje) opredeliti na podlagi predpostavk značilnih za prejšnje obdobje, pri čemer postane raba pojma kot glasbenozgodovinske oznake contradicito in adjecto (Wehnert); drugi način branja sintagme Walterja Wiore pa pomeni, da sta v izrečenem utelešena ugotovitev in dejstvo, ki je last prav romantike in jo kot tako določa v novem glasbenozgodovinskem kontekstu.

S stališča najnovejših muzikoloških razprav bi težko dejali, da je glasbena zgodovina (dokončno) sprejela pojem kot oznako za glasbenozgodovinsko obdobje v svojo periodizacijo evropske glasbe. Še vedno je očitno, da novejša kritika skuša omajati pomen in rabo le-te, vendar pa lahko na osnovi izsledkov muzikoloških razprav druge pol. 20. in začetka 21. stol. razberemo, da so si enotne v ugotovitvi, ki opredeljuje prvo pol. 19. stol. kot romantiko. 
Če je bila romantika v glasbenem zgodovinopisju nekoč zgolj nalepka, je kritika druge pol. 20. stol. prispevala k vzpostavitvi kriterijev, ki pojmu omogočajo uporabnost. Ker pa definicija obdobja izhaja iz definicije pojma, ki ga muzikološka veda še ni dokončno opredelila, je razumljiva tudi negotovost v rabi pojma romantika kot oznake za glasbenozgodovinsko obdobje.

\section{SuMMARY}

Music history surveys of the first half of the 20th century use the term Romanticism as a general designation that covers various musical-cultural phenomena of the 19th century, and as such represents a designation of an entire period of music history. Uncritical transfer of a category as a period into surveys of musical history brought about only a seeming solution in dividing up a markedly heterogenious time into periods, linked only through the term Romanticism. It was only in the second half of the 20th century that musicological research tried to give a scholarly definition of the term that would match the period of musical history itself. A cross section of selected musicological discourses has shown that in the second half of the 20th century and in the beginning of the 21st two models of interpreta- tion have evolved: One in the wake of Blume's ideals, considering Romanticism as a continuation of Classicism, and as such, together with the former, forming a closed, self-contained whole that lasts from the second half of the 18th to the beginning of the 20th century, and another, more recent, which supports the thesis that one can speak of Romanticism only in the first half of the 19th century. Considering the latest musicological research one could hardly say that music history has accepted the term as a designation of a period in its structuring of European music (for good). It is obvious that recent critical minds are trying to undermine the importance and use of the term while, on the other hand, it is also true that the results of musicological discourses of the second half of the 20th and the beginning of the 21st century reveal a unanimous support for designating the first half of the 19th century as Romanticism. 